\title{
Application of ionic liquids in analytical chemistry
}

\author{
Jing-fu Liu, Jan Åke Jönsson, Gui-bin Jiang
}

Room-temperature ionic liquids (ILs) are gaining wide recognition as novel solvents in chemistry. Their application in analytical chemistry, especially in separating analytes, is merited because ILs have some unique properties, such as negligible vapor pressure, good thermal stability, tunable viscosity and miscibility with water and organic solvents, as well as good extractability for various organic compounds and metal ions. This review gives a brief overview of the application of ILs in analytical chemistry, including sample preparation, chromatographic/capillary electrophoretic (CE) separation, and detection.

(c) 2004 Elsevier Ltd. All rights reserved.

Keywords: Ionic liquids; Sample preparation; Capillary electrophoretic separation; Chromatographic separation; Matrix-assisted laser desorption/ionization (MALDI); Sensors

\footnotetext{
Jing-fu Liu*, Gui-bin Jiang Key Laboratory of Environmental Chemistry and Ecotoxicology, Research Center for Eco-Environmental Sciences, Chinese Academy of Sciences, P.O. Box 2871, Beijing 100085, China

Jing-fu Liu, Jan Åke Jönsson Department of Analytical Chemistry, Lund University, P.O. Box 124, S-221 00 Lund, Sweden
}

*Corresponding author. Tel.: +46 4622281 67; Fax: +46 4622245 44; E-mail:

Jing-fu.Liu@analykem.lu.se

\section{Introduction}

Room-temperature ILs, resulting from the combination of organic cations and various anions that may be liquids at room temperature, are salts with melting points of below $\mathrm{ca} .100^{\circ} \mathrm{C}$. Some ILs are liquid at over $400^{\circ} \mathrm{C}$, and some at as low as $-96^{\circ} \mathrm{C}$. The ILs investigated most comprise the organic 1-alkyl-3-methylimidazolium ([C $\left.\left.\mathrm{C}_{n} \mathrm{MIM}\right]\right), \mathrm{N}$-alkylpyridinium, tetraalkylammonium or tetraalkylphosphonium cations. The anions are either organic or inorganic, including: hexafluorophosphate $\left[\mathrm{PF}_{6}\right]$; tetrafluoroborate $\left[\mathrm{BF}_{4}\right]$; trifluoromethylsulfonate $\left[\mathrm{CF}_{3} \mathrm{SO}_{3}\right]$; bis[(trifluoromethyl)sulfonyl $]$ amide $\quad\left[\left(\mathrm{CF}_{3} \mathrm{SO}_{2}\right)_{2} \mathrm{~N}\right]$; trifluoroethanoate $\quad\left[\mathrm{CF}_{3} \mathrm{CO}_{2}\right]$; acetate $\left[\mathrm{CH}_{3} \mathrm{CO}_{2}\right]$; nitrate, and halide [1]. Some ILs are shown in Fig. 1.

The physicochemical properties of ILs depend on the nature and size of both their cation and anion constituents. Their application in analytical chemistry, especially in separating analytes, is merited because ILs have some unique properties, such as negligible vapor pressure, good thermal stability, tunable viscosity and miscibility with water and organic solvents, as well as good extractability for various organic compounds and metal ions [2,3]. Table 1 illustrates some physicochemical properties of the ILs commonly used in analytical chemistry. More detailed information on the properties of ILs can be found in a review [9].

We give a brief overview of the application of ILs in analytical chemistry, which is divided into three areas: sample preparation; chromatographic and CE separation; and, detection. We do not discuss studies on the separation and the determination of ILs [10-12], as this is outside the scope of this review.

\section{Sample preparation}

ILs have negligible vapor pressure and non-flammability as well as good solubility for inorganic and organic compounds. They are therefore useful in liquidliquid extraction (LLE), liquid phase microextraction (LPME), and solid phase microextraction (SPME).

\section{1. $L L E$}

Dai et al. [13] first reported a very highly efficient procedure for extraction of $\mathrm{Sr}^{2+}$ from aqueous phase into disubstituted imidazolium hexafluorophosphates and bis(trifluoromethyl)sulfonylamides by using dicyclohexano-18-crown-6 as extractant.

Later, Visser et al. studied the extraction of $\mathrm{Na}^{+}, \mathrm{Cs}^{+}$, and $\mathrm{Sr}^{2+}$ from aqueous solution to 1-alkyl-3-methylimiazolium hexafluorophosphate $\left(\left[\mathrm{C}_{n} \mathrm{MIM}\right]\left[\mathrm{PF}_{6}\right], n=\right.$ $4,6,8)$ ILs by crown ethers [14], $\mathrm{Cd}^{2+}$, $\mathrm{Co}^{2+}, \mathrm{Ni}^{2+}$, and $\mathrm{Fe}^{3+}$ to ILs $\left(\left[\mathrm{C}_{\mathrm{n}} \mathrm{MIM}\right]\left[\mathrm{PF}_{6}\right]\right.$, $n=4,6$ ) by various organic and inorganic 


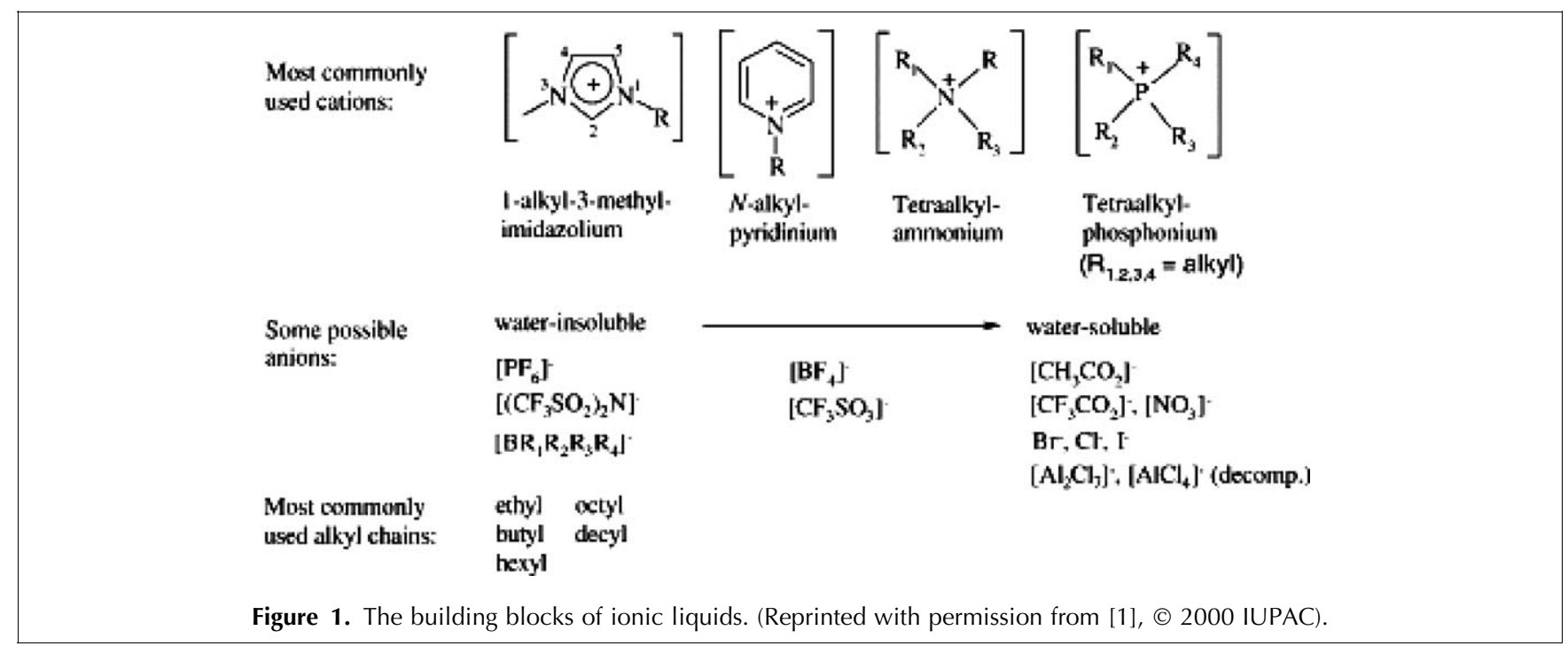

Table 1. Some physicochemical properties of the commonly used ILs in analytical chemistry

\begin{tabular}{|c|c|c|c|c|c|c|}
\hline Ils & $\begin{array}{l}\text { Melting } \\
\text { point }\left({ }^{\circ} \mathrm{C}\right)\end{array}$ & $\begin{array}{l}\text { Density } \\
(\mathrm{g} / \mathrm{mL})\end{array}$ & $\begin{array}{l}\text { Viscosity } \\
\text { (mPa s) }\end{array}$ & $\begin{array}{l}\text { Water } \\
\text { solubility } \\
(\mathrm{g} / 100 \mathrm{~mL})\end{array}$ & $\begin{array}{l}\text { Conductivity } \\
(\mathrm{S} / \mathrm{m})\end{array}$ & References \\
\hline$\left[\mathrm{C}_{4} \mathrm{MIM}\right]\left[\mathrm{PF}_{6}\right]$ & $10,-8$ & $1.36-1.37\left(25^{\circ} \mathrm{C}\right)$ & $148-450\left(25^{\circ} \mathrm{C}\right)$ & 1.88 & $0.14\left(25^{\circ} \mathrm{C}\right)$ & {$[4,5]$} \\
\hline$\left[\mathrm{C}_{6} \mathrm{MIM}\right]\left[\mathrm{PF}_{6}\right]$ & -61 & $1.29-1.31\left(25^{\circ} \mathrm{C}\right)$ & $560-586\left(25^{\circ} \mathrm{C}\right)$ & 0.75 & & \\
\hline$\left[\mathrm{C}_{8} \mathrm{MIM}\right]\left[\mathrm{PF}_{6}\right]$ & & $1.20-1.23\left(25^{\circ} \mathrm{C}\right)$ & $682-710\left(25^{\circ} \mathrm{C}\right)$ & 0.20 & & \\
\hline$[\mathrm{CMIM}]\left[\left(\mathrm{CF}_{3} \mathrm{SO}_{2}\right)_{2} \mathrm{~N}\right]$ & 22 & 1.56 & $44\left(20^{\circ} \mathrm{C}\right)$ & & $0.84\left(20^{\circ} \mathrm{C}\right)$ & {$[2,6,7]$} \\
\hline$\left[\mathrm{C}_{2} \mathrm{MIM}\right]\left[\left(\mathrm{CF}_{3} \mathrm{SO}_{2}\right)_{2} \mathrm{~N}\right]$ & -3 & 1.50 & $34\left(20^{\circ} \mathrm{C}\right)$ & 1.77 & $0.88\left(20^{\circ} \mathrm{C}\right)$ & \\
\hline$\left[\mathrm{C}_{4} \mathrm{MIM}\right]\left[\left(\mathrm{CF}_{3} \mathrm{SO}_{2}\right)_{2} \mathrm{~N}\right]$ & -4 & 1.42 & $52\left(20^{\circ} \mathrm{C}\right)$ & 0.80 & $0.39\left(20^{\circ} \mathrm{C}\right)$ & \\
\hline$\left[\mathrm{C}_{6} \mathrm{MIM}\right]\left[\left(\mathrm{CF}_{3} \mathrm{SO}_{2}\right)_{2} \mathrm{~N}\right]$ & & 1.33 & & 0.34 & & \\
\hline$\left[\mathrm{C}_{8} \mathrm{MIM}\right]\left[\left(\mathrm{CF}_{3} \mathrm{SO}_{2}\right)_{2} \mathrm{~N}\right]$ & & 1.31 & & 0.21 & & \\
\hline$\left[\mathrm{C}_{4} \mathrm{MIM}\right][\mathrm{Cl}]$ & 65,41 & $\begin{array}{l}1.10 \text { (Supercooled } \\
\text { liquid at } 25^{\circ} \mathrm{C} \text { ) }\end{array}$ & Solid & Miscible & Solid & {$[5,6]$} \\
\hline$\left[\mathrm{C}_{2} \mathrm{MIM}\right]\left[\mathrm{BF}_{4}\right]$ & 15 & $\begin{array}{l}1.15\left(30^{\circ} \mathrm{C}\right) \\
1.28\left(25^{\circ} \mathrm{C}\right)\end{array}$ & $37\left(25^{\circ} \mathrm{C}\right)$ & Miscible & & {$[2,3,8]$} \\
\hline$\left[\mathrm{C}_{4} \mathrm{MIM}\right]\left[\mathrm{BF}_{4}\right]$ & -81 & $\begin{array}{l}1.17\left(30^{\circ} \mathrm{C}\right) \\
1.21\left(25^{\circ} \mathrm{C}\right)\end{array}$ & $\begin{array}{l}233\left(30^{\circ} \mathrm{C}\right), 180 \\
\left(25^{\circ} \mathrm{C}\right)\end{array}$ & Miscible & $0.17\left(25^{\circ} \mathrm{C}\right)$ & \\
\hline$\left[\mathrm{C}_{6} \mathrm{MIM}\right]\left[\mathrm{BF}_{4}\right]$ & & & $\begin{array}{l}314\left(20^{\circ} \mathrm{C}\right), 177 \\
\left(30^{\circ} \mathrm{C}\right)\end{array}$ & Miscible & & \\
\hline$\left[\mathrm{C}_{4} \mathrm{MIM}\right]\left[\mathrm{CF}_{3} \mathrm{SO}_{3}\right]$ & 16 & $1.29\left(20^{\circ} \mathrm{C}\right)$ & $90\left(20^{\circ} \mathrm{C}\right)$ & Miscible & $0.37\left(20^{\circ} \mathrm{C}\right)$ & [6] \\
\hline
\end{tabular}

extractants [15], and selective extraction of $\mathrm{Hg}^{2+}$ and $\mathrm{Cd}^{2+}$ from water by task-specific ILs [16].

Chun et al. [17] investigated the influence of structural variation in $\left[\mathrm{C}_{n} \mathrm{MIM}\right]\left[\mathrm{PF}_{6}\right](n=4-9)$ ILs on the selectivity and the efficiency of competitive alkali metal salt extraction by using a crown ether, dicyclohexano18-crown-6, as an extractant.

$\mathrm{Ag}^{+}, \mathrm{Hg}^{2+}, \mathrm{Cu}^{2+}, \mathrm{Pb}^{2+}, \mathrm{Cd}^{2+}$ and $\mathrm{Zn}^{2+}$ were successfully extracted into $\left[\mathrm{C}_{4} \mathrm{MIM}\right]\left[\mathrm{PF}_{6}\right]$ by employing dithizone as a chelator to form neutral metal-dithizone complexes [18]. It was found that the extraction efficiency of IL is higher than that of chloroform at low $\mathrm{pH}$. Furthermore, metal ions can be extracted from aqueous phase into $\left[\mathrm{C}_{4} \mathrm{MIM}\right]\left[\mathrm{PF}_{6}\right]$ and then backextracted into aqueous phase with high recovery by manipulating the $\mathrm{pH}$ value of the extraction system.
Hence, it is possible to separate and to preconcentrate heavy metal ions, as well as to recycle the $\left[\mathrm{C}_{4} \mathrm{MIM}\right]\left[\mathrm{PF}_{6}\right]$.

More recently, eight kinds of $\mathrm{N}$-alkyl aza-18-crown- 6 ethers in ILs, $\left[\mathrm{C}_{n} \mathrm{MIM}\right]\left[\left(\mathrm{CF}_{3} \mathrm{SO}_{2}\right)_{2} \mathrm{~N}\right](n=2-8)$, were investigated as recyclable extractants for separation of $\mathrm{Sr}^{2+}$ and $\mathrm{Cs}^{+}$from aqueous solutions. Because of the $\mathrm{pH}$-sensitive complexation capability of these ligands, it was possible to develop a facile stripping process, permitting both the macrocyclic ligands and the ILs to be recycled. A highly selective system toward $\mathrm{Sr}^{2+}$ was developed after optimizing selection of the macrocyclic ligands and ILs [7]. The same authors also studied the extraction of $\mathrm{Cs}^{+}$from aqueous solution to hydrophobic ILs, without introducing an organophilic anion in the aqueous phase, by using calix-[4]arene-bis(tertoctylbenzo-crown-6) as an extractant and sodium 
tetraphenylborate as a sacrificial cation exchanger to control loss of imidazolium cation to the aqueous solutions by ion exchange [19].

It was reported that octyl(phenyl)- $N, N$-diisobutylcarbamoylmethyl phosphine oxide dissolved in $\left[\mathrm{C}_{4} \mathrm{MIM}\right]\left[\mathrm{PF}_{6}\right]$ enhances the extractability and the selectivity of lanthanide cations compared to when dissolved in conventional organic solvents [20], and pyridinocalix-[4]arene dissolved in $\left[\mathrm{C}_{n} \mathrm{MIM}\right]\left[\mathrm{PF}_{6}\right]$
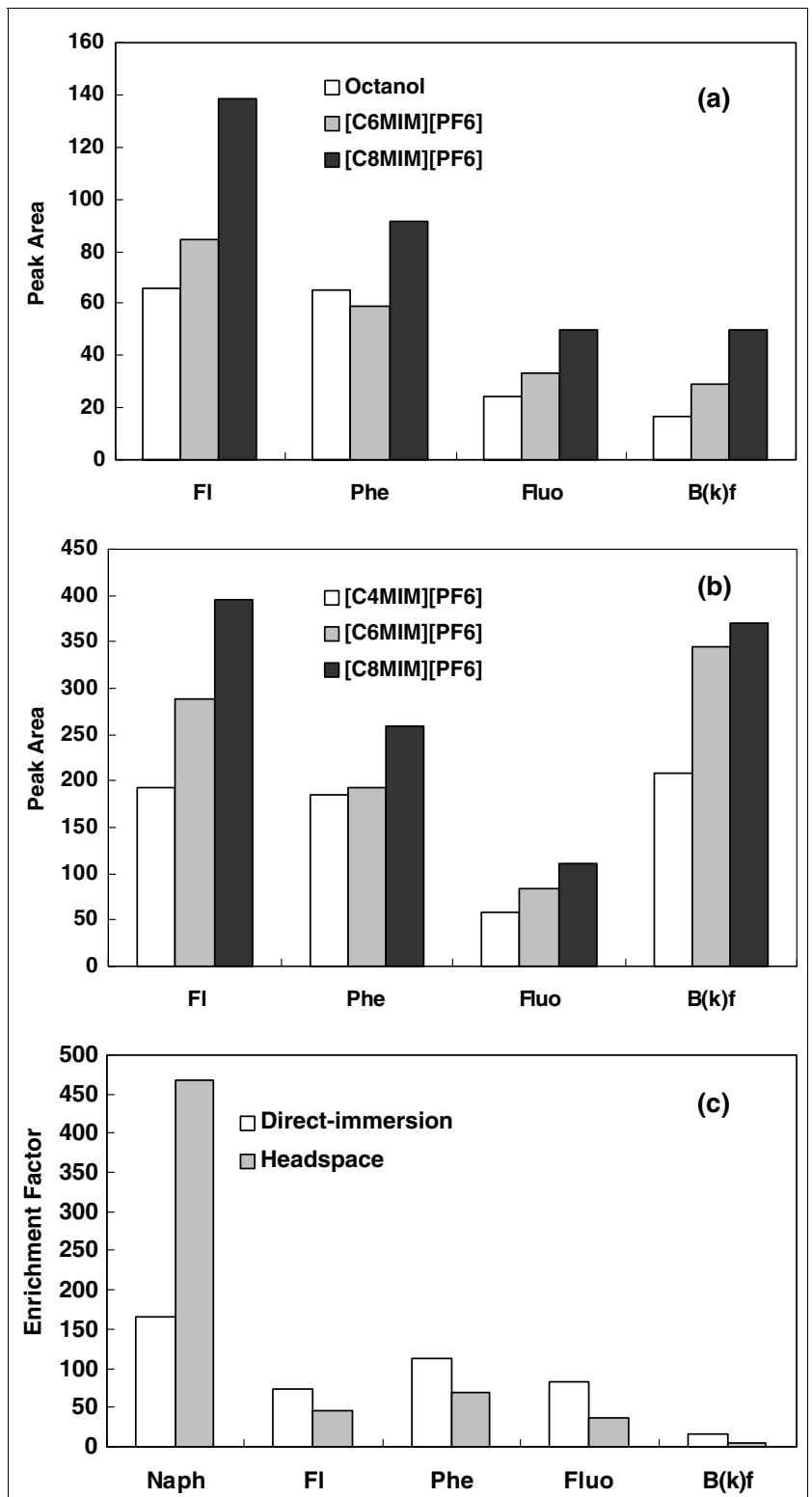

Figure 2. Effect of various solvents and extraction modes on the extraction of PAHs. (a) $5 \mu \mathrm{g} / \mathrm{L}$ PAHs extracted for 5 min using $1 \mu \mathrm{L}$ of solvent; (b) $1 \mu \mathrm{g} / \mathrm{L}$ PAHs extracted for 30 min using $3 \mu \mathrm{L}$ of IL; (c) $5 \mu \mathrm{g} / \mathrm{L}$ PAHs extracted for 30 min using $3 \mu \mathrm{L}$ of $\left[\mathrm{C}_{8} \mathrm{MIM}\left[\mathrm{PF}_{6}\right]\right.$. Naph, Naphthalene; Fl, Fluorene; Phe, Phenanthrene; Fluo, fluoranthene; $\mathrm{B}(\mathrm{k}) \mathrm{f}$, Benzo(k)fluoranthene. $(n=4,6,8)$ showed a high extraction ability and selectivity for silver ions [21].

ILs were also applied to extract various organic compounds including substituted benzene derivatives [22], biofuels [23] and erythromycin-A in bioprocess operations [24] from aqueous solutions. Carda-Broch et al. [6] investigated in detail the solvent properties of $\left[\mathrm{C}_{4} \mathrm{MIM}\right]\left[\mathrm{PF}_{6}\right]$ and determined the $\left[\mathrm{C}_{4} \mathrm{MIM}\right]\left[\mathrm{PF}_{6}\right] /$ water and $\left[\mathrm{C}_{4} \mathrm{MIM}\right]\left[\mathrm{PF}_{6}\right] /$ heptane distribution coefficients for a set of 40 compounds at different $\mathrm{pH}$ values. This study demonstrated that the relative values of $\left[\mathrm{C}_{4} \mathrm{MIM}\right]\left[\mathrm{PF}_{6}\right] /$ water-distribution coefficients $\left(P_{\mathrm{IL} / \mathrm{w}}\right)$ to the corresponding octanol/water coefficients $\left(P_{\mathrm{o} / \mathrm{w}}\right)$ are substance dependent. $P_{\mathrm{IL} / \mathrm{w}}$ are slightly higher than $P_{\mathrm{o} / \mathrm{w}}$ for the compounds containing amine groups, but significantly lower than $P_{\mathrm{o} / \mathrm{w}}$ for acidic and phenolic compounds, while neutral compounds and ionizable compounds with both basic and acid functionalities show similar $P_{\mathrm{IL} / \mathrm{w}}$ and $P_{\mathrm{o} / \mathrm{w}}$ values. By using the shake-flask procedure, the $\log P_{\mathrm{IL} / \mathrm{w}}$ values of 15 polycyclic aromatic hydrocarbons (PAHs) between $\left[\mathrm{C}_{n} \mathrm{MIM}\right]\left[\mathrm{PF}_{6}\right](n=4,8)$ and water, at infinite dilution and $298.1 \mathrm{~K}$, were determined in the range of 3.34-4.36, which increased very slowly with the molar mass of PAHs [25].

\subsection{LPME}

$\left[\mathrm{C}_{n} \mathrm{MIM}\right]\left[\mathrm{PF}_{6}\right](n=4,6,8)$ were adopted as extraction solvents for drop-based LPME of PAHs followed by liquid chromatographic (LC) determination [4]. The unique properties of non-volatility, adequate viscosity and immiscibility with water allow these ILs to be conveniently adopted as extraction solvents in both direct-immersion and headspace LPME. Compared to 1octanol, a larger volume drop of $\left[\mathrm{C}_{8} \mathrm{MIM}\right]\left[\mathrm{PF}_{6}\right]$ can be suspended and it survives for a longer extraction time in the tip of a microsyringe. Therefore, higher enrichment factor for PAHs can be reached, as shown in Fig. 2. For the most volatile $\mathrm{PAH}$, naphthalene, the enrichment factor obtained by headspace LPME was almost threefold that by direct-immersion LPME. The non-volatility of ILs makes them potentially useful for long-time headspace LPME of volatile analytes for obtaining high enrichment factor.

Further research [26] demonstrated that, although $\left[\mathrm{C}_{6} \mathrm{MIM}\right]\left[\mathrm{PF}_{6}\right]$ can suspend a much larger volume of drop on the needle of the microsyringe than conventional solvents, such as 1-octanol and carbon tetrachloride, the method sensitivity was analyte dependent because of different partition coefficients and the relatively large viscosity of $\left[\mathrm{C}_{6} \mathrm{MIM}\right]\left[\mathrm{PF}_{6}\right]$. For example, compared with 1-octanol, $\left[\mathrm{C}_{6} \mathrm{MIM}\right]\left[\mathrm{PF}_{6}\right]$ provides higher sensitivity for 4-tert-octylphenol but lower sensitivity for 4-nonylphenol.

IL-based LPME was also applied to determine formaldehyde in shiitake mushroom [27], and to screen the extractability of 45 typical environmental pollutants 
including BTEX (benzene, toluene, ethylbenzene, and xylene), PAHs, phthalates, phenols, aromatic amines, herbicides, organotin and organomercury compounds by $\left[\mathrm{C}_{n} \mathrm{MIM}\right]\left[\mathrm{PF}_{6}\right](n=4,8)[28]$.

\subsection{SPME}

The IL-drop-based LPME described above is incompatible with gas chromatography (GC) because the ILs are non-volatile. SPME with a disposable $\left[\mathrm{C}_{8} \mathrm{MIM}\right]\left[\mathrm{PF}_{6}\right]$ coating was therefore developed for headspace extraction of BTEX in paints [29]. The SPME fiber was coated with $\left[\mathrm{C}_{8} \mathrm{MIM}\right]\left[\mathrm{PF}_{6}\right]$ prior to every extraction, then the analytes were extracted and desorbed on the injection port of $\mathrm{GC}$, and finally the $\left[\mathrm{C}_{8} \mathrm{MIM}\right]\left[\mathrm{PF}_{6}\right]$ coating on the fiber was washed out with solvents. Compared to the widely used commercially available SPME fibers, this proposed disposable IL-coated fiber has much lower cost per determination, comparable reproducibility, and lower carry-over between each determination. Considering that ILs possess good extractability for various organic compounds and metals ions, and that task-specific ILs can be designed and synthesized for selective extraction of target analytes, this disposable IL-coating SPME should have great potential in sample preparation.

\section{Chromatographic and $C E$ separation}

\subsection{GC}

ILs possess many favorable properties, such as nonvolatility, non-flammability, good solubility of many compounds, high viscosity, and polarity, that make them unique stationary phases in GC. By using two typical ILs, $\left[\mathrm{C}_{4} \mathrm{MIM}\right]\left[\mathrm{PF}_{6}\right]$ and $\left[\mathrm{C}_{4} \mathrm{MIM}\right] \mathrm{Cl}$, as stationary phases for GC, Armstrong et al. [30] studied interactive and retentive behaviors of various compounds with ILs. It was observed that IL stationary phases seem to have a dual nature, i.e., they are capable of separating polar compounds as if they are polar stationary phases and non-polar compounds as if they are non-polar stationary phases. $\left[\mathrm{C}_{4} \mathrm{MIM}\right] \mathrm{Cl}$ interacted much more strongly with proton-donor and -acceptor molecules, while the $\left[\mathrm{C}_{4} \mathrm{MIM}\right]\left[\mathrm{PF}_{6}\right]$ tended to interact more strongly with non-polar solutes. These phenomena were explained by using a linear free energy approach [31].

When used as stationary phases, conventional ILs have some drawbacks, including low maximum operating temperatures $\left(<200^{\circ} \mathrm{C}\right)$, low peak efficiencies for certain analytes, such as alcohols and acids, as well as a tendency to retain tenaciously certain classes of molecules (some acids and bases). To circumvent these shortcomings, two new "bulky" imidazolium cation-based ILs, 1-benzyl-3-methylimidazolium trifluoromethanesulfonate ([BeMIM] $\left.\left[\mathrm{CF}_{3} \mathrm{SO}_{3}\right]\right)$ and 1-(4-meth- oxyphenyl)-3-methylimidazolium trifluoromethanesulfonate ([MPMIM][CF $\left.\mathrm{CO}_{3}\right]$ ), were synthesized and used as GC stationary phases [32]. These new ILs have good thermal stability up to $250^{\circ} \mathrm{C}$, provide symmetrical peak shapes, and still retain the dual-nature selectivity behavior. In addition, the IL stationary phases exhibited better performance for the separation of isomeric compounds than conventional stationary phases, as shown in Fig. 3.

Permethylated $\beta$-cyclodextrin and 2,6-di-methyl$\beta$-cyclodextrin were dissolved in $\left[\mathrm{C}_{4} \mathrm{MIM}\right] \mathrm{Cl}$ to prepare GC stationary phases for chiral separation [33]. Compared to commercial columns with the same chiral selectors, the enantio-resolving capability of the IL-containing columns are unfortunately much lower, probably because the cyclodextrin cavity for chiral recognition was blocked by making an inclusion complex with the imidazolium ion pair.

IL-based GC stationary phase was also applied to determine activity coefficients at infinite dilution of various solutes in the ILs [34-36].

\section{2. $C E$}

The miscibility of ILs with acetonitrile makes it easy to use them for adjustment of analyte mobility and separation in non-aqueous CE. Various types of ILs with different cations and anions, $\left[\mathrm{C}_{n} \mathrm{MIM}\right][\mathrm{X}](n=4,8$; $\mathrm{X}=\mathrm{PF}_{6}{ }^{-}, \quad \mathrm{CH}_{3} \mathrm{COO}^{-}, \quad \mathrm{CF}_{3} \mathrm{COO}^{-}, \quad\left(\mathrm{CF}_{3} \mathrm{SO}_{2}\right)_{2} \mathrm{~N}^{-}$, $\left.\mathrm{CF}_{3}\left(\mathrm{CF}_{2}\right)_{2} \mathrm{COO}^{-}\right)$, were tried as electrolyte additives in acetonitrile for separation of water-insoluble dyes [37], phenols and aromatic acids [38], and polyphenols [39]. The nature of the anionic part as well as the IL concentration influences the general electrophoretic mobility of the buffer system. Separation of the dyes was achieved because they dissociate in the presence of ILs. There is also the possibility of a complex forming between the solute and the electrolyte, and that alters the mobility of the solute. By using [ $\left.\mathrm{C}_{n} \mathrm{MIM}\right]$ $(n=2,4)$ ILs as the running electrolyte solutions, Yanes and co-workers [40] developed a simple, reproducible electrophoretic method for the separation of polyphenols as shown in Fig. 4. With the presence of ILs as running electrolyte, the imidazolium ions coat the capillary walls, thus engendering anodic electroosmotic flow (EOF). The neutral polyphenols $\left(\mathrm{p} K_{\mathrm{a}}=9.5-10.5\right)$ can associate with either the imidazolium cations coating the capillary wall or the free cations in the bulk solution and thus be separated. Experiments show that the association of the polyphenols with the free imidazolium ion seems to dominate. The species of both cation and anion of ILs have also significant influence on separation. Compared with $\left[\mathrm{C}_{2} \mathrm{MIM}\right]\left[\mathrm{BF}_{4}\right],\left[\mathrm{C}_{4} \mathrm{MIM}\right]\left[\mathrm{BF}_{4}\right]$ provided better resolution and a wider separation window, but longer analysis time. For the same organic cation, $\left[\mathrm{C}_{2} \mathrm{MIM}\right]$, no separations were obtained with $\left[\mathrm{CF}_{3} \mathrm{SO}_{3}\right]$ 
(a)

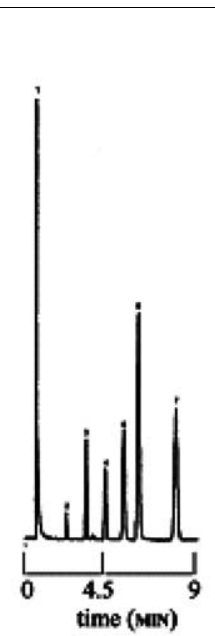

(b)

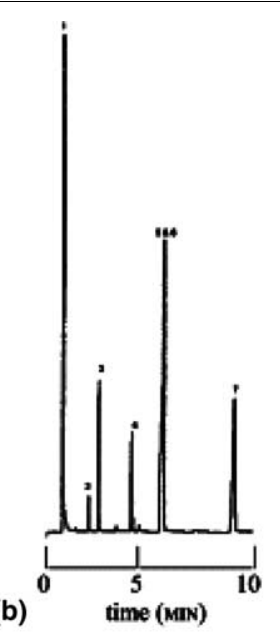

(c)

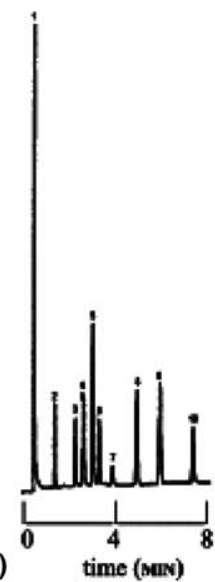

(d)

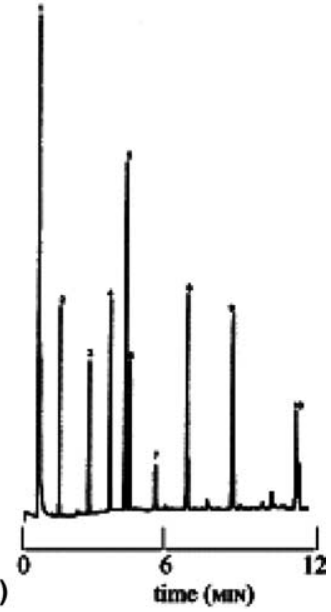

Figure 3. (a, b) Separation of isomeric sulfoxides on: (a) 10-m [BeMIM] $\left[\mathrm{CF}_{3} \mathrm{SO}_{3}\right]$ column and (b) 10-m DB-17 column. 1. $\mathrm{CH}_{2} \mathrm{Cl}_{2}$; 2. p-trifluoromethyl methylphenyl sulfoxide; 3. p-fluoro methylphenyl sulfoxide; 4 . o-chloro methylphenyl sulfoxide; 5 . $m$-chloro methylphenyl sulfoxide; 6 . $p$-chloro methylphenyl sulfoxide; 7. $m$-bromomethylphenyl sulfoxide. Conditions: (a) $170^{\circ} \mathrm{C}$ and (b) $145^{\circ} \mathrm{C}$. (c, d) Separation of PCBs on: (c) $10-\mathrm{m}$ [MPMIM] $\left[\mathrm{CF}_{3} \mathrm{SO}_{3}\right]$ column and (d) 10-m DB-17 commercial column: 1 . hexane; 2. biphenyl; 3. 3-chlorobiphenyl; 4. 2,2'-dichlorobiphenyl; 5. 2,3'-dichlorobiphenyl, 6. 2,4'-dichlorobiphenyl; 7. 2,2', 6-trichlorobiphenyl; 8. 2,2',3-trichlorobiphenyl; 9. 2,2',4,4'tetrachlorobiphenyl; $\quad 10 . \quad 2,2^{\prime}, 4,4^{\prime}, 6,6^{\prime}$-hexachlorobiphenyl. Conditions: $155^{\circ} \mathrm{C}$ for $3 \mathrm{~min}, 3^{\circ} \mathrm{C} / \mathrm{min}$ to $200^{\circ} \mathrm{C}$. (Reprinted with permission from [32], (c) 2003 American Chemical Society).

and nitrate as counterions while the counterion $\left[\mathrm{BF}_{4}\right]$ provided good, reproducible separation.

Similarly, Jiang et al. [41] added imidazolium-based ILs into the running electrolyte to dynamically coat the capillary for CE separation of protein. A common problem in CE separation of protein is the negatively charged surface, caused by the presence of silanol groups of the fused-silica capillary material, which electrostatically attracts the positively charged sites of proteins. When ILs were added to the running electrolyte, basic proteins are repelled by the silica surface of the capillary because of a

surface charge reversal as well as a charge interaction with the analytes; thus, the separation efficiency and repeatability were improved.

Cabovska et al. [42] also investigated the CE behavior of monohalogenated phenols in the presence of $\left[\mathrm{C}_{2} \mathrm{MIM}\right]\left[\mathrm{BF}_{4}\right]$ and compared the results with those obtained with tetraethylammonium tetrafluoroborate $\left(\left[\mathrm{Et}_{4} \mathrm{~N}\right]\left[\mathrm{BF}_{4}\right]\right)$ electrolytes. In both cases, increased halogen size correlated with increased affinity for the electrolyte cation. For isomers, the orthosubstituted isomer exhibited higher affinity than the para isomer.

ILs were also covalently bound to the internal capillary surface (by static coating) in order to reverse the EOF of the silica capillary. This approach was applied to separate positively charged drugs [43], DNA [44] and metal ions [45]. Experiments showed that the covalently ILs-coated capillary could be used for at least $80 \mathrm{~h}$ with relatively stable EOF. Another advantage is that, when ILs were covalently coated, the system was compatible with MS; whereas dynamic coating was not compatible with MS because the ILs were non-volatile.

Additionally, $\left[\mathrm{C}_{n} \mathrm{MIM}\right][\mathrm{X}]\left(n=2,4, \mathrm{X}=\mathrm{BF}_{4}^{-}, \mathrm{PF}_{6}^{-}\right.$, $\mathrm{CF}_{3} \mathrm{SO}_{3}^{-}, \mathrm{Cl}^{-}$) ILs were applied in micellar electrokinetic chromatographic (MEKC) separation of two achiral mixtures (alkyl aryl ketones and chlorophenols) and one chiral mixture (binaphthyl derivatives) [46]. Polymeric surfactants and ILs were added to a low-conducting buffer solution as pseudostationary phase and its modifiers, respectively. The separation of the analyte mixture depended on the interaction of the analytes with the polymeric surfactants, whereas the ILs influenced the elution time and peak efficiency.

\section{3. $L C$}

With the same principle as shown for CE in Fig. 4, imidazolium cations can interact with silanol groups and compete with the polar group of analytes for the silanol groups on the alkylsilica surface in an LC column. Therefore, it can effectively shield residual silanols and improve the peak shapes, while also decreasing the retention time of the analytes. He et al. [47] studied the LC behavior of four basic compounds (norephedrine, ephedrine, pseudoephedrine and methylephedrine) on a $\mathrm{C}_{18}$ column with imidazolium-based ILs added to the eluent at $\mathrm{pH}$ 3.0. The addition of ILs could decrease band tailing, reduce band broadening, and improve resolution. Several ILs were compared as eluent additives, and $\left[\mathrm{C}_{4} \mathrm{MIM}\right]\left[\mathrm{FB}_{4}\right]$ seems to be the best. Furthermore, the imidazolium-based ILs were demonstrated to be compatible with the $\mathrm{C}_{18}$ column.

Another application of ILs in LC is also for the suppression of deleterious effects of free silanols by using imidazolium tetrafluoroborate ILs [48]. The addition of imidazolium tetrafluoroborate ILs to mobile phases at 


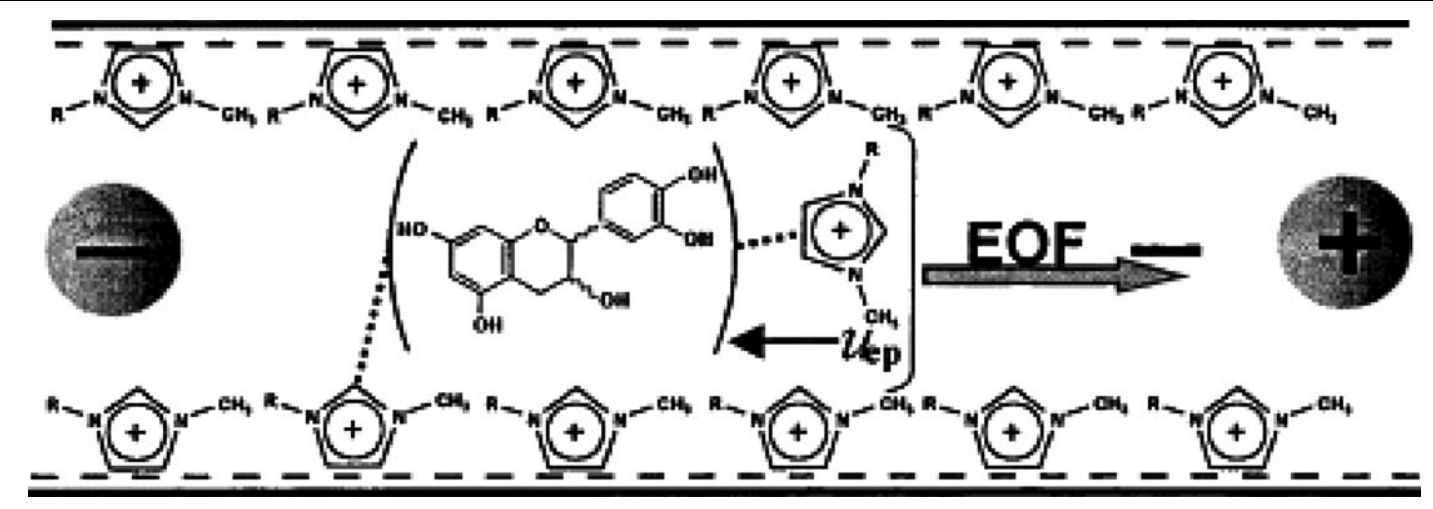

Figure 4. Mechanism for separation of polyphenols using [ $\left.\mathrm{C}_{n} \mathrm{MIM}\right]$-based ILs. (Reprinted with permission from [40], ( 2001 American Chemical Society).

concentrations of $0.5-1.5 \%(\mathrm{v} / \mathrm{v})$ as silanol-blocking additives was markedly more efficient than that of the standard mobile phase additives, such as triethylamine, dimethyloctylamine and ammonia. ILs were also demonstrated to provide reliable lipophilicity parameters of basic drug analytes, as determined by HPLC in gradient mode.

\section{Detection}

\subsection{Sensors}

ILs were employed as the sensing materials of quartz crystal microbalance (QCM) sensor for organic vapors, including toluene, methanol, ethanol, 2-propanol, 1-butanol, acetone, acetonitrile, chloroform, tetrahydrofuran, and ethyl acetate [49]. This application was based on the fact that the viscosity of the IL membrane decreases rapidly because of solubilization of analytes and the change in viscosity varies with the chemical species of the vapors and the types of IL. This results in a frequency shift of the corresponding quartz crystal. The liquid status of ILs at room temperature provided fast diffusion of analytes, so the QCM sensor exhibited a rapid response time (average less than 2 s) to organic vapors with an excellent reversibility. Furthermore, the sensor had a long shelf life because of the zero vapor pressure and stable chemical properties of ILs, which eliminate the possibility of loss of these liquids through vaporization and chemical reaction. This sensor was also applied to determine the solubility of carbon dioxide in a series of imidazolium-based ILs at $25^{\circ} \mathrm{C}$ with $\mathrm{CO}_{2}$ pressures at or less than 1 bar [50].

A novel solid-state amperometric $\mathrm{O}_{2}$-gas sensor based on supported $\left[\mathrm{C}_{2} \mathrm{MIM}\right]\left[\mathrm{BF}_{4}\right]$ porous polyethylene membrane-coated electrodes has been reported [51]. Compared to solid electrolyte gas sensors and classic Clark-type gas sensors, this proposed $\mathrm{O}_{2}$-gas sensor possesses the advantages of easy construction and miniaturization, as well as applicability at room temperature. The drawback of this sensor is that it is restricted to detecting $\mathrm{O}_{2}$ from a dry gas stream, as moisture can be absorbed by the supported $\left[\mathrm{C}_{2} \mathrm{MIM}\right]\left[\mathrm{BF}_{4}\right]$ membrane. It was reported [52] that, when ILs are used in gas sensors, the lower diffusion coefficients of the gaseous analyte in ILs lengthen the response time and limit the attainable steady-state currents. However, the negligible vapor pressure and robust thermal stability of ILs warrant IL-based gas sensors operating under extreme conditions, such as high temperature and high pressure.

\subsection{Matrix-assisted laser desorption/ionization mass spectrometry}

Matrix-assisted laser desorption/ionization mass spectrometry (MALDI-MS) has extended the applicability of MS instruments to both large biological and synthetic molecules. As ILs can produce a much more homogeneous sample solution yet have greater vacuum stability than most solid matrixes, the use of ILs as matrixes could enhance reproducibility and sensitivity.

Armstrong et al. [53] investigated the potential of several different ILs as matrixes for UV-MALDI, by using peptides, proteins, and poly(ethylene glycol) (PEG-2000) as model analytes.

ILs were also used as matrices in MALDI time-of-flight (TOF) MS (MALDI-TOF-MS) to determine DNA oligomer masses directly [54]. These studies demonstrated that some ILs do produce greater spectral peak intensities and lower limits of detection.

A very interesting application of ILs in MALDI-TOFMS analysis of low molecular weight compounds was reported by Santos et al. [55]. By using triethylamine/ $\alpha$-ciano-4-hydroxycinnamic acid as a UV-absorbing IL matrix, fast screening of low molecular weight compounds is performed by thin-layer chromatography (TLC) separation followed by direct on-spot MALDITOF-MS identification with nearly matrix-free mass spectra. For basic low molecular weight compounds, the 
proposed IL matrix seems to favor the formation of a single ion, the protonated analyte molecule, which benefits MS identification. With the advantages of being fast and sensitive, and requiring little sample preparation and manipulation, this technique is suitable for fast screening of low molecular weight compounds.

Mank et al. [56] recently compared IL matrixes, including 2,5-dihydroxybenzoic acid butylamine (DHBB), $\alpha$-cyano-4-hydroxycinnamic acid butylamine (CHCAB), and 3,5-dimethoxycinnamic acid triethylamine (SinTri), with the frequently used solid matrixes, 2,5-dihydroxybenzoic acid (DHB) and $\alpha$-cyano4- hydroxycinnamic acid (CHCA), in MALDI-MS. The IL matrixes considerably enhanced the shot-to-shot reproducibility. DHBB conserved the broad applicability of its solid analogue, DHB, while reducing MALDI-induced fragmentation of monosialylated glycans and gangliosides. Thus, it was the superior IL matrix for MALDI-MS analysis of oligosaccharides and polymers. CHCAB and SinTri were the best IL matrixes for peptides and high molecular weight proteins, such as IgG, respectively. Furthermore, it was demonstrated that the solvent properties and MALDI matrix properties of ILs could be combined to enable fast, direct screening of enzymatic reactions.

\subsection{Vis/NIR and Raman spectroelectrochemistry}

Compared to traditional electrolyte solutions, $\left[\mathrm{C}_{4} \mathrm{MIM}\right]\left[\mathrm{BF}_{4}\right]$ was found to be an advantageous medium that offers a broader window of electrochemical potentials, and favorable optical properties for in situ Vis/NIR and Raman spectroelectrochemistry of nano-carbon species (single-walled carbon nanotubes and fullerene peapods) [57]. The Raman spectra were reported to be poorly reproducible at larger anodic potentials in acetonitrile or aqueous media because of the photoanodic decomposition of tubes and peapods. However, in ILs, photoanodic decomposition was not observed and spectra were almost completely recoverable in backward potential scans. But, $\left[\mathrm{C}_{4} \mathrm{MIM}\right]\left[\mathrm{BF}_{4}\right]$ has no significant Raman bands that would overlap those of nanotubes or peapods, while, in acetonitrile solutions, for example, the $\delta \mathrm{C}-\mathrm{H}$ band overlaps the bands of tubes or peapods.

\section{Conclusions and future perspective}

Because of their unique properties, ILs have been successfully applied in various areas of analytical chemistry, especially in separation of analytes, and more applications are expected. ILs in supported liquid membrane extraction [58-60], which has been studied for industrial separation, is reasonably expected to be applied in sample preparation. Chiral ILs might hopefully be applied in chromatographic/CE separation of chiral mixtures. It also seems that ILs have significant advantages when used as matrixes for MALDI-MS, so more research in this subject might widen the application of MALDI-MS in analysis of both low and high molecular weight substances. As ILs have wide electrochemical windows and large conductivities, they have great potential to be used as sensors in electrochemical analysis.

\section{Acknowledgements}

This work was supported by the National Natural Science Foundation of China $(20377045,20477052)$ and the National Basic Research Program of China (2003CB415001, 2002CB412308).

\section{References}

[1] K.R. Seddon, A. Stark, M.-J. Torres, Pure Appl. Chem. 72 (2000) 2275.

[2] H. Olivier-Bourbigou, L. Magna, J. Mol. Cat. A 182-183 (2002) 419.

[3] J. Dupont, R.F. de Souza, P.A.Z. Suarez, Chem. Rev. 102 (2002) 3667.

[4] J.-F. Liu, G.-B. Jiang, Y.-G. Chi, Y.-Q. Cai, J.-T. Hu, Q.-X. Zhou, Anal. Chem. 75 (2003) 5870.

[5] J.G. Huddleston, A.E. Visser, W.M. Reichert, H.D. Willauer, G.A. Broker, R.D. Rogers, Green Chem. 3 (2001) 156.

[6] S. Carda-Broch, A. Berthod, D.W. Armstrong, Anal. Bioanal. Chem. 375 (2003) 191.

[7] H. Luo, S. Dai, P.V. Bonnesen, Anal. Chem. 76 (2004) 2773.

[8] T. Nishida, Y. Tashiro, M. Yamamoto, J. Fluorine Chem. 120 (2003) 135.

[9] C.F. Poole, J. Chromatogr. A 1037 (2004) 49.

[10] P. Stepnowski, A. Muller, P. Behrend, J. Ranke, J. Hoffmann, B. Jastorff, J. Chromatogr. A 993 (2003) 173.

[11] C. Villagran, M. Deetlefs, W.R. Pitner, C. Hardacre, Anal. Chem. 76 (2004) 2118

[12] C. Villagran, C.E. Banks, C. Hardacre, R.G. Compton, Anal. Chem. 76 (2004) 1998.

[13] S. Dai, Y.H. Ju, C.E. Barnes, J. Chem. Soc., Dalton Trans. (1999) 1201.

[14] A.E. Visser, R.P. Swatloski, W.M. Reichert, S.T. Griffin, R.D. Rogers, Ind. Eng. Chem. Res. 39 (2001) 4596.

[15] A.E. Visser, R.P. Swatloski, S.T. Griffin, D.H. Hartman, R.D. Rogers, Sep. Sci. Technol. 36 (2001) 785.

[16] A.E. Visser, R.P. Swatloski, W.M. Reichert, R. Mayton, S. Sheff, A. Wierzbicki, J.H. Davies, R.D. Rogers, Environ. Sci. Technol. 36 (2002) 2523.

[17] S. Chun, S.V. Dzyuba, R.A. Bartsch, Anal. Chem. 73 (2001) 3737.

[18] G.-T. Wei, Z. Yang, C.-J. Chen, Anal. Chim. Acta 488 (2003) 183.

[19] H. Luo, S. Dai, P.V. Bonnesen, A.C. Buchanan III, J.D. Holbrey, N.J. Bridges, R.D. Rogers, Anal. Chem. 76 (2004) 3078.

[20] K. Nakashima, F. Kubota, T. Maruyama, M. Goto, Anal. Sci. 19 (2003) 1097.

[21] K. Shimojo, M. Goto, Anal. Chem., 76 (2004) 5039.

[22] J.G. Huddleston, H.D. Willauer, R.P. Swatloski, A.E. Visser, R.D. Rogers, Chem. Commun. (1998) 1765.

[23] A.G. Fadeev, M.M. Meagher, Chem. Commun. (2001) 295.

[24] S.G. Cull, J.D. Holbery, V. Vargas-Mora, K.R. Seddon, G.J. Lye, Biotechnol. Bioeng. 69 (2000) 227.

[25] J.-F. Liu, Y.-G. Chi, J.-F. Peng, G.-B. Jiang, J.Å. Jönsson, J. Chem. Eng. Data 49 (2004) 1422. 
[26] J.-F. Liu, Y.-G. Chi, G.-B. Jiang, T. Chao, J.-F. Peng, J.-T. Hu, J. Chromatogr. A 1026 (2004) 143.

[27] J.-F. Liu, J.-F. Peng, Y.-G. Chi, G.-B. Jiang, Talanta (in press).

[28] J.-F. Liu, Y.-G. Chi, G.-B. Jiang, J. Sep. Sci. (in press).

[29] J.-F. Liu, N. Li, G.-B. Jiang, J.Å. Jönsson, J.-M. Liu, M.-J. Wen (submitted)

[30] D.W. Armstrong, L. He, Y.-S. Liu, Anal. Chem. 71 (1999) 3873.

[31] D.W. Armstrong, J.L. Anderson, J. Ding, T. Welton, J. Am. Chem. Soc. 124 (2002) 14247.

[32] J.L Anderson, D.W. Armstrong, Anal. Chem. 75 (2003) 4851.

[33] A. Berthod, L. He, D.W. Armstrong, Chromatographia 53 (2001) 63.

[34] A. Heintz, D.V. Kulikov, S.P. Verevkin, J. Chem. Eng. Data 46 (2001) 1526.

[35] A. Heintz, D.V. Kulikov, S.P. Verevkin, J. Chem. Eng. Data 47 (2002) 894.

[36] A. Heintz, D.V. Kulikov, S.P. Verevkin, J. Chem. Thermodyn. 34 (2002) 1341

[37] M. Vaher, M. Koel, M. Kaljurand, Chromatographia 53 (2001) S302.

[38] M. Vaher, M. Koel, M. Kaljurand, Electrophoresis 23 (2002) 426.

[39] M. Vaher, M. Koel, M. Kaljurand, J. Chromatogr. A 979 (2002) 27.

[40] E.G. Yanes, S.R. Gratz, M.J. Baldwin, S.E. Robison, A.M. Stalcup, Anal. Chem. 73 (2001) 3838.

[41] T.-F. Jiang, Y.-L. Gu, B. Liang, J.-B. Li, Y.-P. Shi, Q.-Y. Ou, Anal. Chim. Acta 479 (2003) 249.

[42] B. Cabovska, G.P. Kreishman, D.F. Wassell, A.M. Stalcup, J. Chromatogr. A 1007 (2003) 179.

[43] W. Qin, S.F.Y. Li, Electrophoresis 23 (2002) 4110.

[44] W. Qin, S.F.Y. Li, Analyst (Cambridge, UK) 128 (2003) 37.
[45] W. Qin, H. Wei, S.F.Y. Li, J. Chromatogr. A 985 (2003) 447.

[46] S.M. Mwongela, A. Numan, N.L. Gill, R.A. Agbaria, I.M. Warner, Anal. Chem. 75 (2003) 6089.

[47] L. He, W. Zhang, L. Zhao, X. Liu, S. Jiang, J. Chromatogr. A 1007 (2003) 39.

[48] R. Kaliszan, M.P. Marszał, M.J. Markuszewski, T. Baczek, J. Pernak, J. Chromatogr. A 1030 (2004) 263.

[49] C. Liang, C.-Y. Yuan, R.J. Warmack, C.E. Barnes, S. Dai, Anal. Chem. 74 (2002) 2172.

[50] R.E. Baltus, B.H. Culbertson, S. Dai, H. Luo, D.W. DePaoli, J. Phys. Chem. B 108 (2004) 721.

[51] R. Wang, T. Okajima, F. Kitamura, T. Ohsaka, Electroanalysis 16 (2004) 66.

[52] M.C. Buzzeo, C. Hardacre, R.G. Compton, Anal. Chem. 76 (2004) 4583.

[53] D.W. Armstrong, L.-K. Zhang, L. He, M.L. Gross, Anal. Chem. 73 (2001) 3679.

[54] S. Carda-Broch, A. Berthod, D.W. Armstrong, Rapid Commun. Mass Spectrom. 17 (2003) 553.

[55] L.S. Santos, R. Haddad, N.F. Hoehr, R.A. Pilli, M.N. Eberlin, Anal. Chem. 76 (2004) 2144.

[56] M. Mank, B. Stahl, G. Boehm, Anal. Chem. 76 (2004) 2938.

[57] L. Kavan, L. Dunsch, ChemPhysChem 4 (2003) 94.

[58] L.C. Branco, J.G. Crespo, C.A.M. Afonso, Chem. Eur. J. 8 (2002) 3865.

[59] E. Miyako, T. Maruyama, N. Kamiya, M. Goto, Chem. Commun. (2003) 2926.

[60] E. Miyako, T. Maruyama, N. Kamiya, M. Goto, Biotech. Lett. 25 (2003) 805 